This wcrk was supported by the US Energy Research and Development Administration, Division of Nuclear Research and Applications.

Pisnted in the United States of America. Avaribble from

National Technical Information Service

U.S. Department of Commerce

5285 Port Royl Roed

Springfiold, VA 22161

Pice: Printed Copy 53.50 Miczofiche $\$ 2.25$

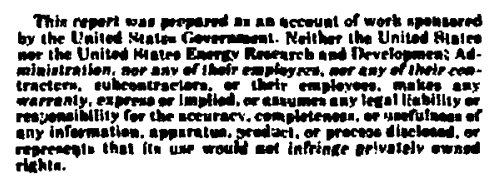

Thentian. 


\title{
REVIEW OF PARTITIONING PROPOSALS FOR SPENT NUCLEAI FUELS
}

\author{
by \\ David F. Bowersox:

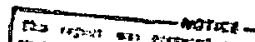

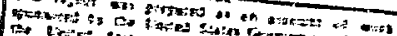

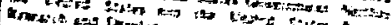

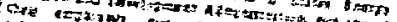 \\ Whitis \\ Wats?

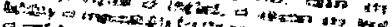

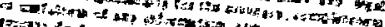

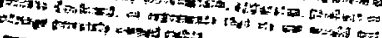 \\ ABSTRACT
}

\begin{abstract}
The initial phase of atudy about recovery of valuable fisuion products from gpent nuclear fuels has been to review various partitioning proposals. This report briefly degcribes the aqueous Purex process, the anlt transport process, melt refining, fuoside volntility process, and gravimetric seporations. All these processes sppear to be possible technically, but further research will be necessary to determine which are mont feasible. This review includes gerseral recommendations tor experimentel research and development of several partitioning options.
\end{abstract}

\section{INTRODUCTION}

A program has been initiated at the Los Alamos Scientific Labotatory (LASLi to demonstrate the recovery of valuable fission products from spent nuclear fuels. The spent fuel could be used more ef. ficiently. The actinides are extremely valuable and if the long-lived isotopes were completely removed and used or recycied, the remaining wate would be fas easier to atore and manage. The literature on reprocessing nuclear fuels has been studied and this report surnmarizes the findingn. This summary doey not signify a completion of the review; in fact, both the literature search and consultations with scientists active in this field should be continued. The collected information will be used to propose programs to study the parameters needod for devising viable processes This research will be conducted at LASL at our present and proposed research facilities. Experience at LASL in studies of the metallurgy and chemiatry of plutonium, uranium, and the actinides will be applicable to these new programs.

A Fuel Cycle Task Force surveyed the fuel cycle recently und reported their findinge (Ref. 1). They concluded that explorazory mining, milling, enrich ment. and fabrication of utanium for nuclear fuel have been satisfactorily demcinstrated and that this part of the reactor progtam is operable. However. even though proceusing of spent uuclear fuels has been studied extenuively, they found that reprocessing has not been dimonstrated adequately. They recognized problems in recycling because of the radioactivity of the sprent fuel and the necesuity for environmental protection. The anfeguards problems ar I the questions of licessing probnbly cannot be overcome hy private industry alone. The Task Force recommenced that the Energy Research and Development Administration (ERDA) proceed with demonstration programs and, if necessary. build government facilities to demonstrate commetcial fuel reprocessing.

This report brienly describes the types of seactors planned for the United States and the spent fuels to be generated in them. It then covers aqueous and pyrocherical processes and in particular, the ex. pected partitioning problems. Finally, it recom. mends approsches to experimental studies of eeveral phases of these probleme. 


\section{PItOPOSED REACTOHS}

The three major renctor syotems now propessed to fotnerate commetcial pouser in the linited States ate the lightstwer reater. the trigh-tumperatute nas.

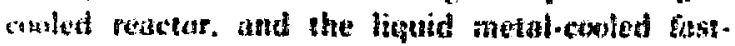
biecter reactor. The first of these to operate com.

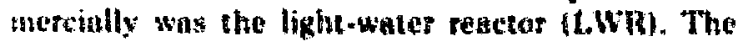
I.WT is fuoled with stighty aniched 100 sealed in

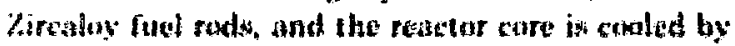
urdinary liphas wates. The uraniwn. of a mixture of utranitzn and phutunium prodaced during reaceor aperation. could the recstored from the spent hot

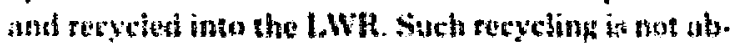
\$4luedy necessary as lon as more uroniun is atallahle. However, recycling would lawez powes chists and sestul in a larger numbur of operational neacturs being on line for the same smount af initial

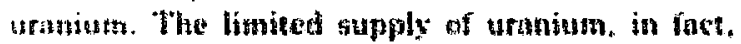
casthi Hit axtented by about s5: by recyeling spent toel as a mixed uranium -phtsoniutio uxide. Recyel. ing has been considered extensisely and the concert

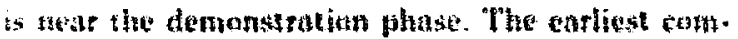
swercial atse of the mixed oxite fuet is cotimated at 1941.

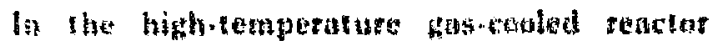

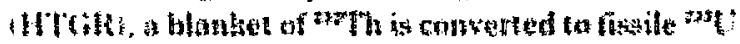
hy an initial reaktor fuel of axt. The wat is uged to

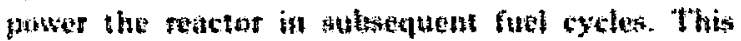

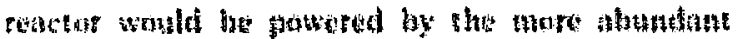

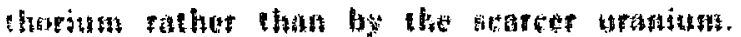
Ciraphine is used extensivaly in the Hoth as a motsturatar. claddiang. and solector material on that

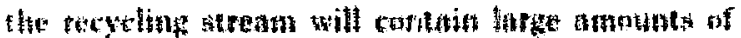

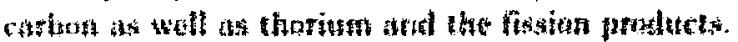
the thell ts still in the design and prototype

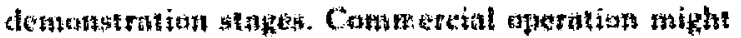

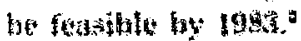

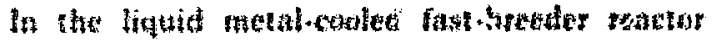

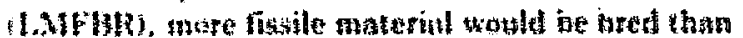

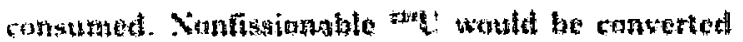

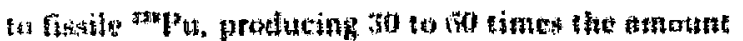

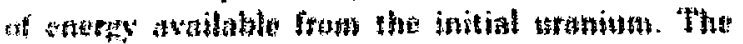

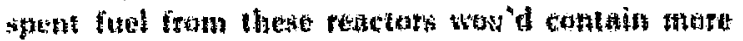

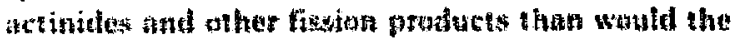

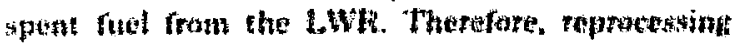

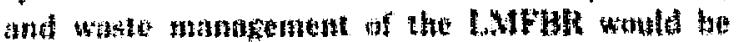
more diffeuts. 'The LMBthe is ifl in the conceptal state ant commercial develapmen is non expected

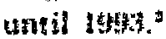

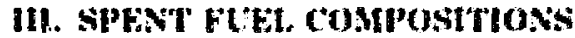

The apreation of a nuelone reactur products significant quantities of radivactive materinls. Some of these materints interiors with the continued ef focient operation of the seactor. atsuatly by fissien prothet absorption of the netsons needed to sustain the nuclear chain teactiss. At srane proint the fuel

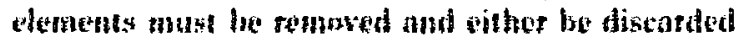

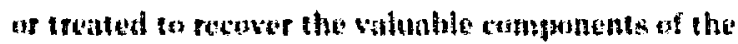

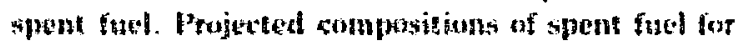
she sarints teactor convents are given in Table 1 "

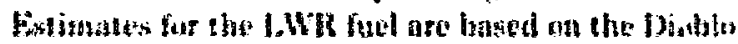

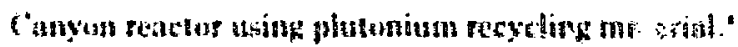

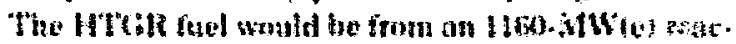

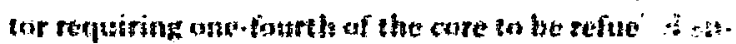

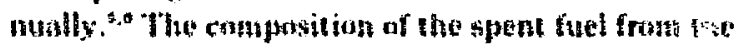

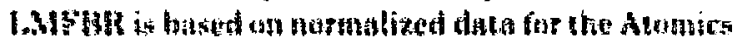

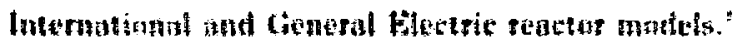
the spent futel enmpositions wary berause af the dit. forences on the initial reactor fuets and in the

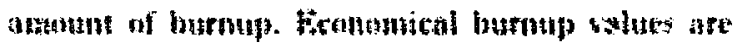

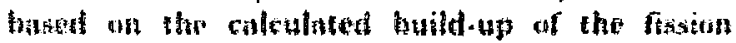

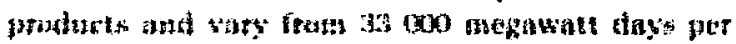

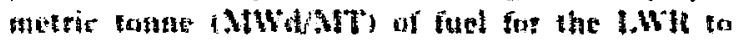

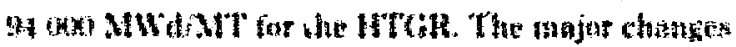
in complotititus are the increanes in the contentat. lions af fission gzedturts, actinides, and platonians in

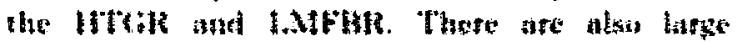

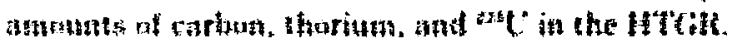

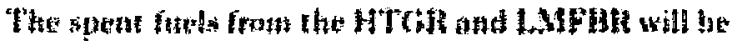

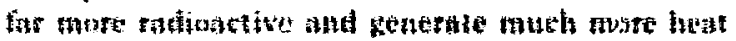
that thase from the 1.34 ll.

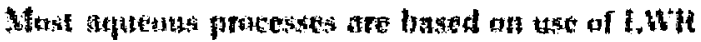

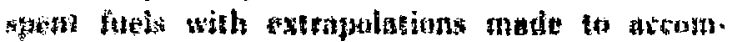

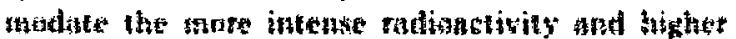
heat-yenezation rates of the later spetal farls.

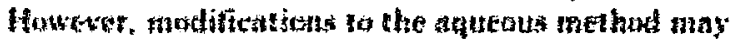

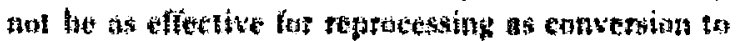
nomationotis systems.

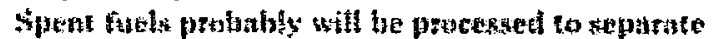
at leasl phutanium and utznium for recyeling intes

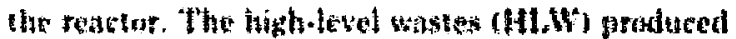
in this stomatian ate derined as thase aquedus

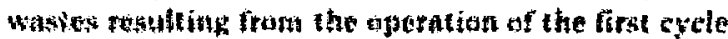

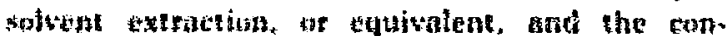

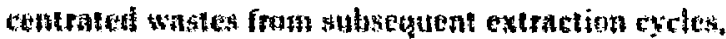
af equivalent, in a facility for reprocessing ieraditited teactor fuels. The HLW narmally will contain most 
TABLE I

\section{CONPOEITIONS OF APJNT REACTOR FUELS}

\begin{tabular}{|c|c|c|c|}
\hline \multirow[b]{2}{*}{ Specte: } & \multicolumn{3}{|c|}{$\begin{array}{c}\text { Henvy Metal } \\
\text { ke/MT }\end{array}$} \\
\hline & LWR* & HTGR* & LMFBR \\
\hline 10 & 1124 & $\ldots$ & $\ldots$ \\
\hline $\mathrm{PuO}_{\mathfrak{u}}$ & 11.0 & $\cdots$ & $\ldots$ \\
\hline Clad & 278 & $\ldots$ & $\ldots$ \\
\hline Fiksim Product: & 32.0 & 98.9 & 33.3 \\
\hline Actinides & 5.83 & 2.2 & 0.8 \\
\hline Pu & $\ldots$ & 1.7 & 100 \\
\hline c & $\ldots$ & 11726 & $\ldots$ \\
\hline $\mathrm{Th}$ & $\ldots$ & 840 & $\ldots$ \\
\hline L & $\ldots$ & 37.2 & 854 \\
\hline U (Make-up) & $\ldots$ & 11.3 & $\ldots$ \\
\hline U (Recycle) & $\ldots$ & 7.5 & $\ldots$ \\
\hline $\mathbf{b}$ & $\cdots$ & 0.97 & $\cdots$ \\
\hline li $i$ & $\cdots$ & 0.17 & $\ldots$ \\
\hline Fe & $\ldots$ & 0.48 & $\ldots$ \\
\hline Oxides & $\ldots$ & 119 & $\ldots$ \\
\hline Sitieon Carbida & $\ldots$ & 45 & $\ldots$ \\
\hline Stninless Steel & $\ldots$ & $\ldots$ & 1372 \\
\hline
\end{tabular}

"2t on MWUAMT at a specific powet of $30 \mathrm{MW} / \mathrm{MT}$.

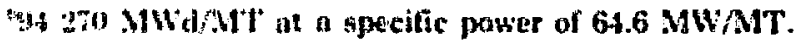

'Hiended cose and blonket assembly: $\$ 3000 \mathrm{M}$ Wd/MT

at it afjectife proser of as MW/MT.

of the reactur-produced fission protucts and actinites. These products generete enough hent to se. quire subshamial cowling and emit large anounts of pountially herardaus tonizing tediation. Present rogulanions nequire that the HL,W be solitified within $5 \mathrm{gr}$ und be shipped to a federai repository within 10 yo of genatration.

One aprosch to fnanging the HLW is to divide it into fractions of different half-lives: that is, to partition the waste." Storage volumes for the long-lived redionctive tatuduen would be reduced greaty and nuch of the wast: could be discarded within a rearonable grologicul time. Foz example, if the aclinides were removed the huzard of the remaining waste at 1000 yr would be equivalent to that in a naturally oceurring body of ore. Short-lived isotopes coutd be used commercially or stored until relatively nontaxic. The tong-lived fractions, such as the actinides, could bo ured commercially, placed in fuet
For transmutation, or stored for a long period. If storage is required. it would be more easily done than for the undivided high-level wante because of teductions in the maks, heat output, and penetrating sadiation of most of the waste. However, rather large separation factors, sometimes as high an $10^{\circ}$, may be required for the long-lived isotopes and such high fnctors have not been demorstrated. ${ }^{\text {:0 }}$

The long-lived isotopes could solve exeral of our prestnt energy problems; energy sources include

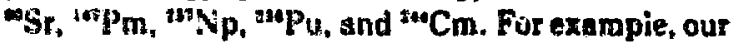
first spacecraft to pass Jupitet and Saturn was powered by ${ }^{m p} \mathrm{Pu}$. Isotopes such as " $\mathrm{S} r$ could be used to power unmanned radar cites, and " $\mathrm{Cs}$ might replace ${ }^{\circ} \mathrm{Co}$ in radiogtaphicel applications. Significant quantities of the platinum metals will also be produced in these reactoss; if recovered, these could be valuable." Dix, in fact, has estimeted that the 
isotopes in spent fuels could be worth billions of dollars. ${ }^{12}$ Rohrman believes that americium, curium, the noble metals, and the rare gases can be recovered and that the sale of these elements would lower the cust of power significantly. ${ }^{13}$ If no market existed for a separated isotope. it could probably be transmuted into less radioactive species by recvcling through the reactor.

\section{Phocessing}

Several principles apply to all processing schemes. All avoid adding chemicais that could be particularly troublesome in later processing. Processing and storage space are kept as small as possible by minimizing required volumes. Because of the radioactivity of the spent fuels, most operation and maintenance are conducted remotely. Therefore, the equiprient should be kept as simple as possible. Finally, solvents and process streams are recycled whenever feasible to keep waste volumes as low as possible.

Bartlett et al. have published a comprehensive evaluation of transuranic partitioning of high-level fuel reprocessing waste by solvent extraction and ion exchange methods. ${ }^{10}$ "These authors concluded that partitioning by conventional reprocessing methods, particularly solvent extraction. is preferable to a revision of reprocessing operacions. Reasons tor this conclusion were not evaluated in their report. Under present and forthcoming rezulations, altemative methods might prove superior to the Purex process. Conventiona: Purex processing may be altered to provide for partitioning, but formidable problems must be solved. ${ }^{\text {to. } 15}$ Pyrochemical processes are aiso technologically feasible and may prove to be economically preferable and also result in fewer problems with operation and waste management. 'Therefore, not onily the aqueous Purex process but also the salt transport, melt refining, and nuoride volatility processes are presented in this summary. A reference to flotation scheme is also given. This does not cover all possible methods, for certainly other methods such as laser-enhanced processing may be developed. The processes described, however, appear to be well worth further study.

All processing of spent fuel starts with storage in order to eliminate some of the shore-lived, very active fission products. Fuel in storage, by definition, is net in productive use so that short storage times are desirable. Particularly with LMFBR fuels, the plutonium in the spent fuel represents a sizable investment. The pyrochemical procedures can be conducted remotely after shart storage times. In aqueous processing, longer storage may be necessary.

The second step in the processing is either dissolu. tion of the entire element or separation of the claciding. In the chop-leach method adopted for the Purex process, up to $1 \%$ of the fuel remains with the cladding residues. Other decladding methods also have drawbacks. For example, at higher burnups, oxide fuels often adhere to the cladding wall so that vibration does not separate all of the fuel. Dissolution of clad in anhydrous hydrochloric acid results in a highly corrosive system, and dissolution in liquid metals leads to a difficult physical separation of molten metal and oxides. However, some of these separations may prove to be quite adequate with ad. ditional scouting studies and evaluations. In the following discussions of processing methods, different decladding procedures are propused. In most cases, these methods are interchangeable. For example, the liquid zinc dissolution proposed for the salt tran. sport process could be used in the Purex process as well. Therefore, systematic studies of decladding should be useful regardless of which orocess is finally chosen.

\section{AQUEOUS PROCESSES AND THE PUREX PROCESS}

Probably aqueous processing using an organic solvent extraction for purification is the most lamiliar method for separating uranium, plutonium, and specially produced actinides from various im. purities. A generalized flow sheet for such processing is given in Fig. 1. The solvent extraction step can be replaced by a number of other purification methods such as precipitation or ion exchange. Jon exchange is not used in many cases beceuse solids that form during processing plug the columns and because of possible radiolysis of the exchange resin.

The flowsheet shown in Fig. 1, however, is typical of aqueous processing. After a storage period, the end pieces and hardware would be removed from the fuel element and the cladding would be chopped into small pieces. Separation of the element would be effected by ball-milling, vibration, of leaching of the spent fuel. The residue, which would be radioactive. 


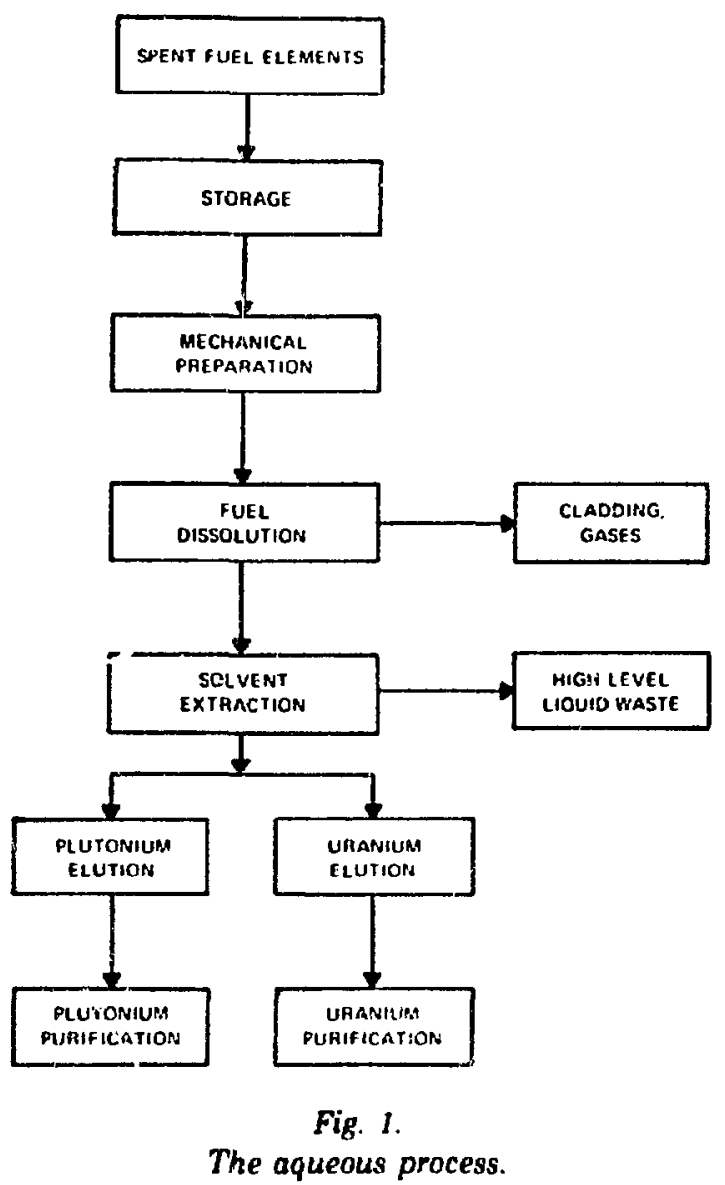

would be stored as wasto. After separation, the fuelwould be dissoived and other purification sters would be performed. Finally, the purified uranijun and plutonium solutions would be resynthesizer, into fuel elements.

Bartlett et al. reported that Purex processing would be the mont useful of the various equeous methods in commertial recycling asd jartitioning processes. ${ }^{10}$ It is the only aqueous proriess discussed in this report.

The flowsheet for the Purex process after fuel dis. solution is given in Fig. 2. After storage and mechanical remonal of the end pieces, the fuel element is separated from the cladding by a chop-leach Inethod using nitric acid for the dissolution. The aqueous feed is treated with tributyl phosphate (TBP) in an organic ciluent to separate uranium and plutonium from the tission products. The aqueous phase becomes the high-ievel liquid waste (HLLW). The proposed composition of this phase at the

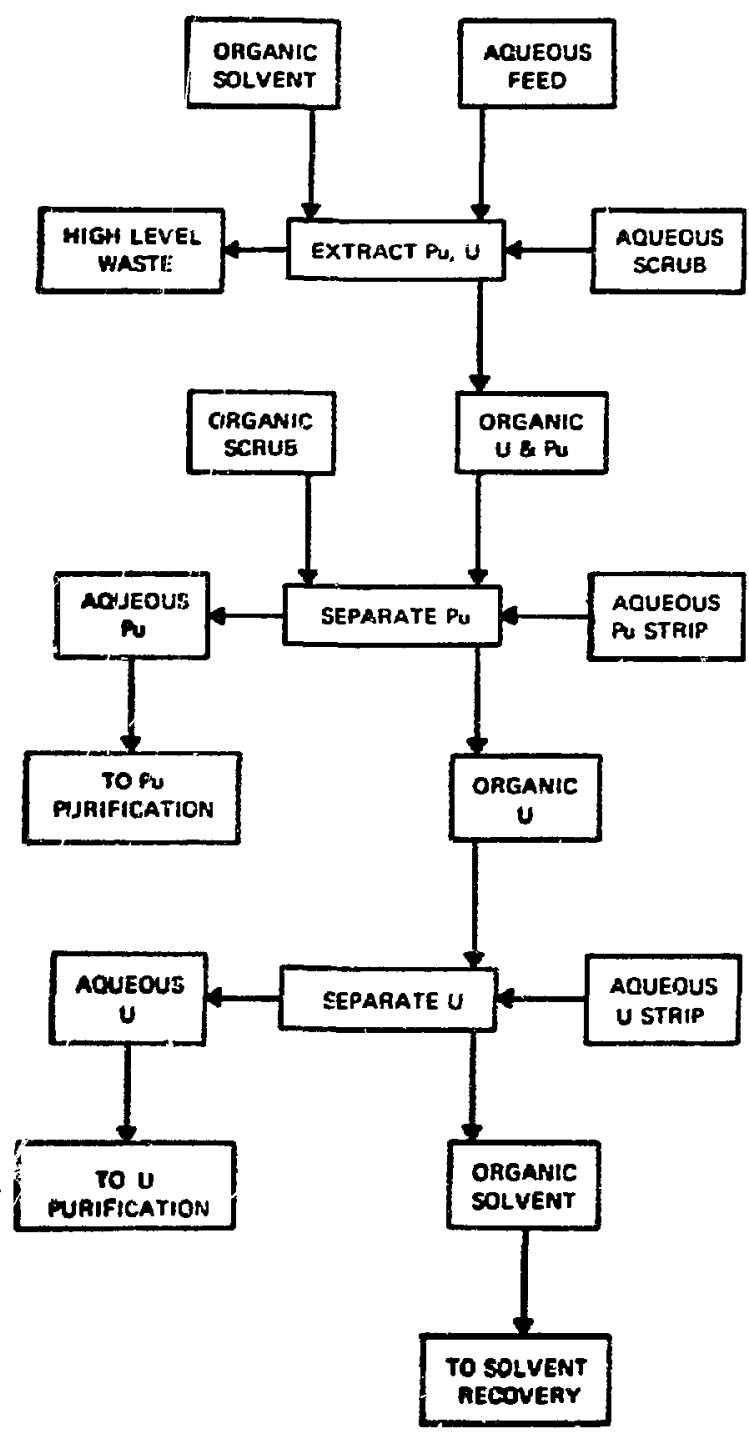

Fig. 2.

The Burex process.

Barnwell Allied-General Niclenr Services processing plant, which is currenily under construction, is given in Table II. Present plans are to solidify and store this waste.

The organic solvent is then selectively stripped of the plutonium and the uranium into separate aqueous streams. These streams are purified as necessary before synthesizing the uranium and, for mixed oxides, the plutonium into fuel. 
TABLE II

\section{COMPOSITION OF BARNWELL HLLW}

\section{Origin \\ Dissolution}

Fission product

Fission product

Fission product

Fission product

Fission product

Fission product

Fission product

Fission product

F:ssion product

Fission product

Fission product

Fission product

Fission pioduct

Fission product

l'otal fission product

Actinides

$\begin{array}{cl}U & 0.074 \\ \mathrm{~Np} & 0.0036 \\ \text { Pu } & 0.0007 \\ \text { Am } & 0.0038 \\ \mathrm{Cr} & 0.0002\end{array}$

Total actinides

0.115

0.046

\begin{tabular}{ccc} 
Opecies & & Sonc. (molea/l) \\
\cline { 1 - 1 } & & \\
HNO, & & $\approx 1$ \\
$\mathrm{Se}$ & & 0.0003 \\
$\mathrm{Br}$ & & 0.0003 \\
$\mathrm{Rb}$ & & 0.0071 \\
$\mathrm{Sr}$ & & 0.0166 \\
$\mathrm{Y}$ & & 0.0082 \\
$\mathrm{Zr}$ & & 0.072 \\
$\mathrm{Mo}$ & & 0.1665 \\
$\mathrm{Tc}$ & & 0.016 \\
$\mathrm{Ru}$ & & 0.041 \\
$\mathrm{Rh}$ & & 0.0086 \\
$\mathrm{Pd}$ & & 0.025 \\
$\mathrm{Ag}$ & & 0.0013 \\
$\mathrm{Cd}$ & & 0.0021 \\
ln & & 0.00002
\end{tabular}

Impurities and

corrosion products

Goluble nuclear

poison

TBP decomposition

Fission priduct

Fission product

Fission product

Fission product

Fission product

Fission product

Fission product

Fission product

Fission produci

Fission product

Fission product

Fission produc:

Fission product

Fission produce
Species Conc. (molea/l)

$\begin{array}{ll}\text { Sn } & 0.00038 \\ \text { Sb } & 0.00016 \\ \text { Te } & 0.0074 \\ \text { Cs } & 0.034 \\ \text { Hn } & 0.022 \\ \text { La } & 0.0167 \\ \text { Ce } & 0.032 \\ \text { Pr } & 0.016 \\ \text { Nd } & 0.051 \\ \text { Pm } & 0.0004 \\ \text { Sm } & 0.0118 \\ \text { Eu } & 0.002 \\ \text { Gd } & 0.0014 \\ \text { Tb } & 0.00002\end{array}$

$\begin{array}{ll}\text { Na } & 0.0077 \\ \text { Fe } & 0.063 \\ \text { Cr } & 0.0068 \\ \text { Ni } & 0.0024 \\ \text { Gd } & 0.1007\end{array}$

$\mathrm{PO}^{-3}$

0.037

-35 $000 \mathrm{MWdMT}$ fuel after 150 -day storage.

'Waste is in 568 \&.

The conventional Purex process must be modified extensively for efficient partitioning. If the AGNS flowsheet is adopted, plutonium and neptunium must be coextracted into T'BP by stabilizing the nepturium in the hexavalent state. It would be far more effective to remove stabilized neptuniuin with the plutonium and uranium during the initial processing of the fuel. In either case, studies are needed to determine the stabilizer, an alternative reductant for stripping plutonium from the organic solvent so that the solvent can be recycled, and methods for recycling all solutions."

If the precipitstes formed during aging of the HLLW before partitioning conl,ain actinides, a dissolution method must be found. After dissolution, chemical similarities of the rare earths to americium and curium will make secarations of americium and curium extremely difficult. Processes such as Talspeak have been developed for small-scale separations, but they are very complex. ${ }^{10-10}$ Large volumes of waste would certainly be gererated with such methods and, at the low acidities required, the actinides may well precipitate. Actinide separations after reve earth removal should be fairly straightforward and could involve either golven: extraction or ion exchange.

Bartlett et al. proposed a massive program to develop a modified Purex process for effectivi partitioning. ${ }^{10}$ The research cost was estimated to be three million dollars, but the potential gain is far greater. Bond and Leuze were directing snother study to develop partitioning for LWR wastes, " but 
this has evidently been dropped to develop a closed fuel cycle without partitioning.

The major advantages of the Purex process include the large amount of published research available and the length of time the method has been used, since the late forties, in separating uranium and plutonium from scrap and fission products. The Purex process has been used in nearly every exisiing major fuel processing facility and many proposals have izeen made for modifying it for partitioning.

However, even after $30 \mathrm{yr}$ of lievelopment, the Pures process is stili imperfect. The wastes from spent fuels will be far more radioactive and generate much more heat than those encountered in research and weapons operations. Problems were encountered when the process was used at the National Fuels Services Plant. Precipitates and inextractable species are formed during prosessing and aging. ${ }^{27.18}$ The decladding operation Jeaves plutonium and uranium in the cladding residues. ${ }^{12}$ Spent LMFBR fuels containing more than $20 \%$ plutonium dioxide may not totally dissolve in the leaching solution. The method for solidifying the HLLW stream is being develuped. Therefore, the Purex proctss is still not fully developed.

\section{THE SALT TRANSPORT PROCESS}

The salt transport process, developed at Argonne National Laboratory (ANL), appears to be quite promising for small-scale, on-site fuel recycling. The general flow sheet for the process is shown in Fig. 3 . After 30 day storage, the frel elements are declad in liquid zinc at $850^{\circ} \mathrm{C}$. The dissolved slad would be decanted from the spent oxide fuel, and the oxides would be treated with a molten salt and alloy mixture to remove selected fission products and reduce the oxides to metal. The metals would then be treated with molten allcys and salts for further purification and, finally, synthesized into recycled fuel.

Most of the gaseous firsion products would be released into the cover gasi during decladding; any krypton, xenon, iodine, and tritium remaining should be released during the reduction step. Fission products such as rubidiuin, cesium, strontium, beryllium, and samarium should transfer into the salt phase during reduction. An additional contact with salt could be made to improve such a transfer.

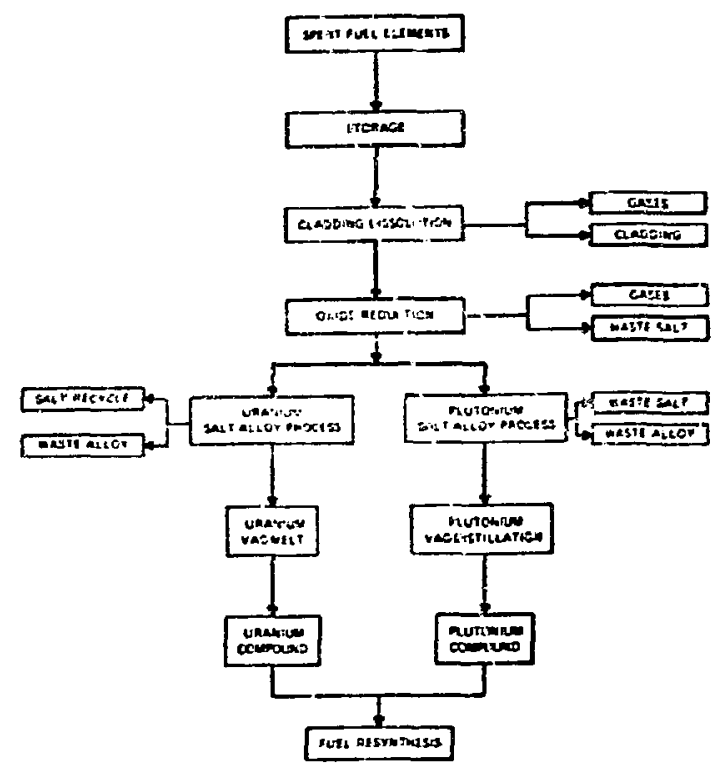

Fig. 3.

Salt transport processing.

Uranium metal, which is virtually insoluble in the selected alloy. would be formed from the oxide and precipitated whereas plutonium would remuin in the alloy phase.

The alloy would be separated from the salt phase and precipitate, and fission products such as yttrium and the rare earths would be removed through a series of salt-extraction cells. In a second series of salt-extraction cells, plutonium would be separated from elements such as zirconium, niobium, molybdenum, technetium, ruthenium, rhodium?, and pailadium. The purified plutonium would then be separated from the alloy by vacuum distillation.

The uranium precipitate would be dissolved in a suitable alloy and purified by transfer through a series of salt-extraction cells similar to those for plutonium purification. The purified uranium would be reprecipitated, separated, and vacuum melted into an ingot. Finally, uranium and plutonium would be oxidized to form a fuel.

The rare earths are removed from the actinides during the salt transfer process. A salt transfer cell is shown in Fig. 4. The element $A$, which is being purified, transfers from the initial donor alloy into the liquid salt carrier in exchange for element $B$, which is common to the salt and the acceptor alloy. 


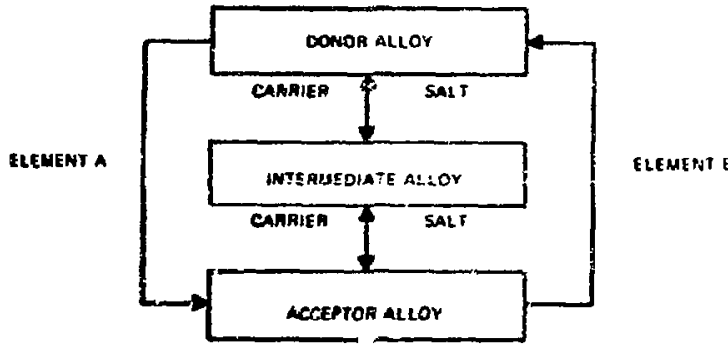

Fig. 4.

Salt-transport cell.

Element $A$ is trangferred through the salt into the intermediate alloy and then into the acceptor alloy, where it is exchanged with element $B$. The reaction series in a chloride salt may be written as

$\mathrm{A}$ (donor alloy) $+\frac{\mathrm{n}}{2} \mathrm{BCl}_{2} \leq \mathrm{ACl}_{\mathrm{n}}+\frac{\mathrm{n}}{2} \mathrm{~B}$ (donor alloy).

$$
\begin{aligned}
& \mathrm{ACl}_{\mathrm{n}}+\frac{\mathrm{n}}{2} \mathrm{~B} \text { (acceptor alloy) } \\
& \quad=\frac{\mathrm{n}}{2} \mathrm{BCl}_{2}+\mathrm{A} \text { (acceptor alloy). }
\end{aligned}
$$

The overall reaction becomes

$$
\begin{aligned}
& \text { A (donor alloy) }+\frac{n}{2} B \text { (acceptor alloy) } \\
& \quad=\frac{n}{2} B \text { (donor alloy) + A (acceptor alloy). }
\end{aligned}
$$

The alloys and salts are selected so that the extraction results in a purification of element $A$. Better separations are obtained with one or more ailoys of intermediate composition between the donor and asceptor alloys. The rare earth elements would be retained in the salt phase and the actinides could be isolated in selected alloys during the transport process.

Steunenberg et al. showed the feasibility of the salt tra spo.t process," but laboratory tests are needed to determine suitalle operation conditions for effective separations. Data on solubilities and transport of actinides 28 functions of salt mixtures, alloy compositions, and temperature will be needed.

The advantages of this process include the small volumes of waste generated as stable solids. The uncomplicated equipment would require little space, and would be maintained remotely. The process chemicals are radiation resistant and processing could be used effectively at a reactor site with little increase in safeguards or environmental protection requirements. Expensive, long distance ir $r$ nsport of fuel would be eliminated. The method would separate and isolate the sare earth fission products and potentially could partition the actinides very ef fectively.

Disadvantages of the salt transport prosess include the time required to develop a demonstrated system and the need for adritional bench seale sesearch. This type of grocessing. particularly in the nuclear industry, is far less familiar than Jurex processing. However, pilot studies and uranium fuel reprocessing in the Second Experimental Breeder Reactor (EBR-II) indicate that this process can be applied successfully.

\section{MELT REFINING PROCESS}

Melt refining is a relatively simple procedure for limited purification of metallic fuels. It has been ts.sed successfully in recycling urenium in the EBR. II. 20 The process could be useful for mixed oxide, carbide, or nitride fuels if a reduction step is placed after decladiding. A flow sheet for the modified process is given in Fig. 5. After the deciadding and reduction steps, the mixture would be maintained at high temperature for several hours with ar oxide slag such as magr.esia. The melk, contailing most of the uranium and plutonium, would then the poured into an ingot and resynthesized into fuel. Data indicate that about two-thirds of the fission products will be separated by this technique, but that molybienum. ruthenium, and zirconium will remain with the fuel. In fast reactors, where neutron poisoning should be minimal, this process might be satisfactory. Calculation of acceptable concentrations of fission: products will be needed in evaluating this technique. Laboratory experiments will be necessary to determine the behavior of the actinides.

The fission products and uranium remaining in the slag from melt refining would be recovered by a skull reclamation process, developed at ANL, ${ }^{2 s}$ which is similar to the salt transport process. Metallic uranium fuel for the EBR-II was recycled remotely for over 5 yr by the melt-refining proces,3. The skull reclamation process was develored in the laboratory but was not used because EBR-II was converted to a test reactor. ${ }^{26}$ The demonstrated success of the melt-refining process and its relative 


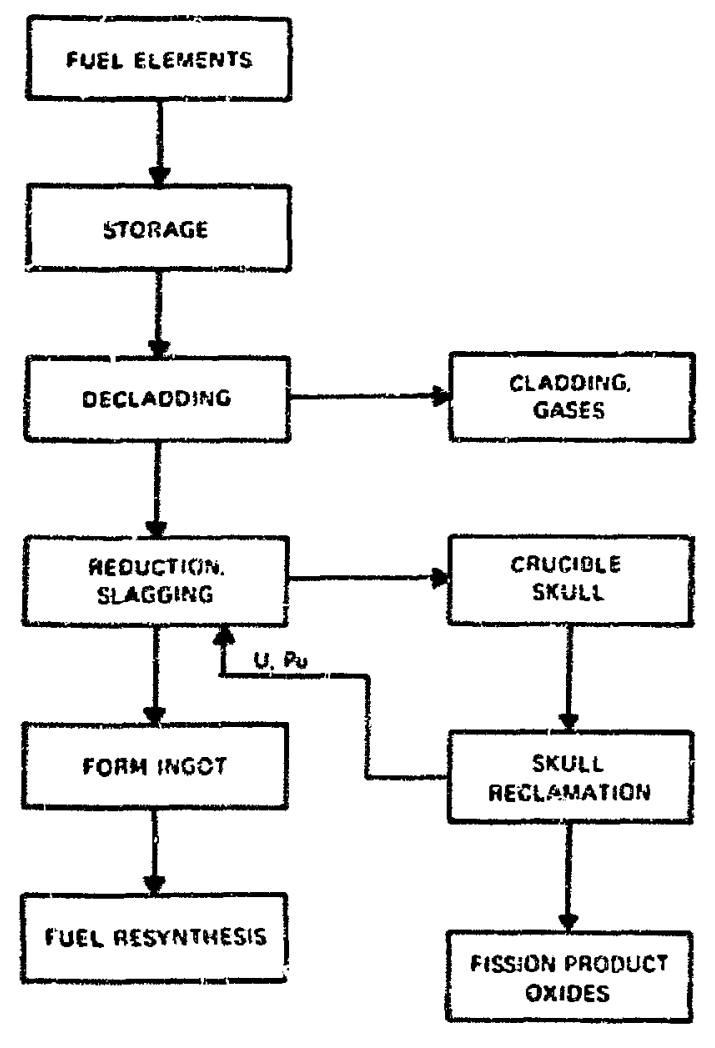

Fig. 5.

Melt rofining processing.

simplicity indicate that it would be a promising method for at least interim processing of spent fue!s.

\section{FLUORIDE VOLATILITY PROCESS}

The flowsheet for the fluoride volatility prozess is given in Fig. 6 . Because the equipment must withstand fluorine and its compounds, the cladding can be volatilized in anhydrous hydrochloric acid. The spent fuel would then be treated with fluorine gas or an interha'ogen fluoride at $300^{\circ} \mathrm{C}$ in a fluidized bed to volatilize uranium hexafluoride and most of the other volatile fluorides such as ruthenium, niobium, antimony, molybdenum, neptunium and tellurium. Fluorine would then be used to volatilize plutonium hexafluoride at $55 \mathrm{G}^{\circ} \mathrm{C}$. The nonvolatile fluorides, that is, those elements in Groups I, II, III, and IV of the Periodic Table, would remain in the solid fluidized bed. Ruthenium-lis.jbium pentafluoride

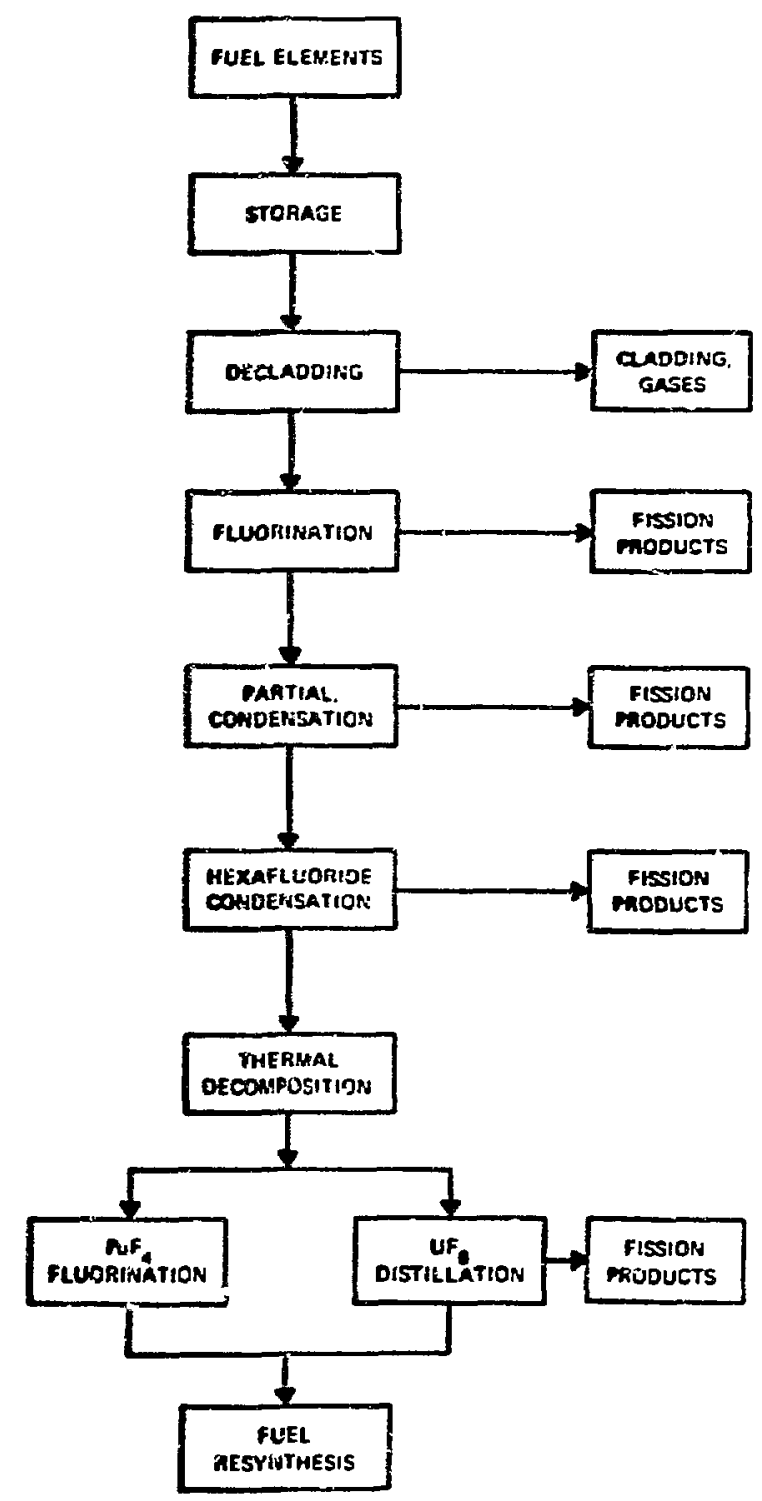

Fig. 6.

Fluoride volatility process.

would be trapped in partıal condensers and transferred into a bed of sodium fluoride. Thus, most of the wastes would be in solid form. Off-gases such as xenon, krypton, iodine pentafluoride, tritium, fluorine, and oxygen would be trapped and compressed. 
The plutonium hexafluoride would be separaied from uranium hexafluoride and the remaining fission products by thermal decomposition. The uranium hexafluoride would then be distilled and the purified uranium and plutonium fluorides would be converted to mixed oxide fuel.

There has been extensive study of uranium hexafluoride and fluoride volotility in the program associated with gaseous diffusion for enrichment of the ${ }^{2 s} \mathrm{U}$ isotopes. ${ }^{26}$ Fluoride volatility processes have been used in the cormmercial refining of uranium at the Allied Chemical Plant at Metropolis, IL, and in development of methods for processing several types of irradiated fuels. There have been basic and pilot scale preparation and transport of plutonium hexafluoride. ${ }^{27}$ Fluid-bed calcination of redioactive waste solution has been conducted at Idaho National Engineering Laboratory. Laboratory studies of the fluorination of simulated oxide fuels at ANL showed that fluorination and subsequent separation of uranium and plutonium from spent fuels is feasible. ${ }^{28}$

The uncertuinty in using the fluoride volutility process is primarily over the high levels of radioactivity in the high-plutonium fuels of the LMFBR. The process for decladding by anhydrous hydrochloric acid should be developed, and the handling of the solids in a processing plant of this nature needs refinement. Checks are needed to ensure that plutonium losses to the fluidized bed are low. The behavior and separation of the actinides must also be determined.

Major advantages of the process include the number of studies and applications mentioned, and the relative simplicity of the equipment and of the process itself. Disadvantages include the extreme corrosiveness of fluorine and its compounds and the intense radioactivity of the fluoride products.

\section{GRAVIMETKIC SEPARATIONS}

Another method for separating fission products would be by using the differences in densities of the oxides, as shown in Table III..$^{29}$ After decladding, the spent fuel would be subject to further oxidation and then placed in a ferrofluidic medium such as that proposed by Khalafalla and Reimers. ${ }^{30,82}$ The density of this fluid, they claim, can be magnetically adj'1sted from 1 to $50 \mathrm{~g} / \mathrm{cm}^{3}$. Such separations, if feasi-
TABLE III

\section{DENSITIES OF SELECTED OXIDES}

\begin{tabular}{lc} 
Oxide & Density $\left(\mathbf{g} / \mathrm{cm}^{8}\right)$ \\
\cline { 2 - 2 } & \\
$\mathrm{UO}_{2}$ & 10.96 \\
$\mathrm{U}_{3} \mathrm{O}_{8}$ & 8.30 \\
$\mathrm{PuO}_{2}$ & 11.48 \\
$\mathrm{NpO}_{2}$ & 11.11 \\
$\mathrm{CmO}$ & $\cdots$ \\
$\mathrm{AmO}_{2}$ & 11.68 \\
$\mathrm{PtO}_{2}$ & 10.2 \\
$\mathrm{MoO}_{2}$ & 6.47 \\
$\mathrm{ZrO}_{2}$ & 5.6 \\
$\mathrm{RuO}_{2}$ & 6.97 \\
$\mathrm{PdO}^{2}$ & 8.70 \\
$\mathrm{ReO}_{2}$ & 11.4 \\
$\mathrm{RhO}_{2}$ & 8.2 \\
$\mathrm{RuO}_{2}$ & 6.97 \\
$\mathrm{Ce}_{2} \mathrm{O}_{3}$ & 6.86 \\
$\mathrm{Cs}_{2} \mathrm{O}_{3}$ & 4.25
\end{tabular}

ble, would be extremely useful in spent fuel processing.

Khalafalla and Reimers separated nonferrous metals from residues of incinerated urban refuse by density differences. ${ }^{31.32}$ A colloidal suspension of magnetite in kerosene was placed between the poles of a magnet, and, by adjusting the density of the suspension, the solid refuse particles were separated into light and heavy components.

This method would be simple and could be operated remotely. Any study would necessarily start with a thorough examination of the results of Khalafalla and Reimers. Extensive developmental work would be necessary.

\section{RECOMMENDATIONS AND SUMMARY}

Although the Purex process has been used for scrap recovery and small-scale actinide separations, it should not be adopted for partitioning without proof that it is indeed the best available method. As the heat content and radioactivity of the spent fuels become larger, problems in the Purex scheme become critical. Even at the Nuclear Fuel Services Plant problems were encountered in processing spent uranium oxide fuels. The successful processing 
of uranium fuel in the EBR-II shows that pyroprocessing can be accomplished. The pilot plant studies of the skull reclamation proress ${ }^{26}$ also indicate that the salt transport process can be adapted to a commercial scale plant. The fluoride volatility process also has significant potential advantages.

Whether the development task for one process will be greater than for others is unclear. The technological problems associated with pyrochemical processes are not insurmountable. It would appear reasonable to initiate studies of alternate processing. Such programs could well lead to simplified processing, partitioning, and waste management at far less overall cost than presently projected. Although proponents of the Purex proces 3 now claim that it is the classical, conventional method for reprocessing, it was not always the accepted method. Just as the Purex process replaced other, less desirable methods, so one of the pyrochemical processes could well become the conventional method after extensive research and development.

Pyrochemical processing of spent reactor fuels is technologicaliy feasible and studies of such processes would fir into the capabilities and the areas of interent at LASL. Areas in which studies could be developed include the processes reviewed in this summary; that is, salt transport, melt refining, and fluoride volatility processing. Programs of research should be proposed using any one (or more than one in combination: of these methods to develop a workable plan for recycling oxide, carbide, and other fuels for both the LWR and the LMFBR and for separating the actinides from the waste streams. In fact, detailed proposals for study of the salt transpcrt process are being written.

The limited time before spent fuel from the LWR must be processed, probably at the Barnwell plant by the Purex process, means that some form of aqueous processing will be used for several years. However, as more reactors are on line and as more fuel must be recycled, the use of pyrochemical processes could replace the present method. By the time LMFBR fuels must be reprocessed, pyrochemical processes that are economically and technologically superior to the Purex process for both LWR and LMFBR fuels should be in use.

Spent fuels must be separated from the cladding in all these processes, and the chop-leach treatment proposed for AGNS does not dissolve all the fuel. Although residues containing plutonium and uranium could be treated with a nitric-hydrofluoric acid leach, or by a fluoride volatility process, a secand corrosive processing stream would result. Additional studies of separation by chemical means, by liquid metals, and by mechanical treatments are needed for all processes. Such studies could be made at LASL.

Personnel at LASL should become familiar with many of the programs now being sonducted on reprocessing. The Sandia Solidification Project ax Sandia Laboratory, Albuquerque, for example, is a different approach to waste soildification through use of an inorganic ion exchange resin. Research at the Idaho National Engineering Laboratory and Battelle Northwest Laboratory indicates thet bidentate compounds can be used to separate americium and other trivalent actinides from many wastes. Studies of reprocessing and waste management in Europe should also be of interest. The potential in laser separations should also be continuously evaluated.

These recummendations will be developed into an on-going program. The tash of finding the best method for reprocessing nuclear wastes will be challenging. The value could, however, be very great in lowering the cost of power, using the actinides and other fission products, and in simplifying the tasks of waste management.

\section{REFERENCES}

1. T. R. Clark, E. E. Kintner, F. K. Pittman, and W. R. Voigt, Jr., "Nuclear Fuel Cycle," Energy Research and Development Administration report ERDA-33 (March 1975).

2. J. O. Blomeke, "Radioactive Wastes from the LWR Fuei Cycle," presented at Third Annual Conference on Nuclear Power and Environmental Assessment, Berkeley, CA, (September 1975).

3. J. O. Blomeke, C. W. Kee, and J. P. Nichois, "Projections of Radioactive Wastes to be Generated by the U.S. Nuclear Power Industry," Oak Ridge National Laboratory report ORNL-TM-3965 (February 1974).

4. D. E. Deouigi, Battelle Northwest Laboratories, unpublished data, May 1972. 
5. L. V. Colby, R. C. Dahlberg, and S. Jaye, "HTGR Fuel and Fuel Cycle Summary Description," General Atomic Laboratory report GA-10233 (May 1971).

6. Keith E. Asmussen, Gulf General Atoming, unpublished data, August 1972.

7. T. D. Wolsko, Argonne National Laboratory, unpublished data, November 1969.

8. "Siting of Fuel Reprocessing Plants and Waste Management Facilities," Oak Ridge National Laboratory report ORNL-44E1 (July 1970).

9. U.S. Atomic Energy Commission, "High-Level Radioactive Waste Management Alternatives," WASH-1297 (May 1974).

10. J. W. Bartlett, L. A. Bray, L. L. Burger, R. E. Burns, and J. L. Ryan, "Feasibility Evaluation and R\&D Program Plan for Transuranic Partitioning of High Level Fuel Reprocessing Waste," Battelle Northwest Laboratories report BNWL-1776 (1973).

11. L. L. Clark, F. P. Roberts, J. C. Shepperd, and K. D. Kaser, "A Market Analysis of Fission Product Rh, Pd, Re, and Tc," Battelle Northwest Laboratories report BNWL-1690 (February 1973).

12. G. P. Dix, "The Beneficial Utilization of Nuclear Waste Products," presented at Second Annual Waste Management Symposium, Tucson, AR, March 25, 1976.

13. C. A. Rohrman, "Values in Spent Fuel from Power Reactors," Battelle Northwest Laboratories report BNWL-25 (May 1968).

14. W. E. Bond and R. E. Leuze, "Feasibility of the Partitioning of Commercial High-Level Wastes Generated in Spent Nuclear Fuel Reprocessing, "Annual Progress Report for FY-1974, Oak Ridge National Laboratory report ORNL-5012 (January 1975).

15. W. E. Bond, H. C. Clairborne, and R. E. Lueze, "Methods for Removal of Actinides from High-Level Wastes," Nucl. Technol. 24, 362 (1974).
16. Z. Kolarik, G. Koch, H. H. Kuesel, and J. Fritsch, "Separation of Americium and Curium from Highly Radioactive Waste Solution," Karlsruhe Laboratory report KFK-1553 (1972).

17. W. Ochsenteld, H. Schneider, and 3. Theiss, "Aqueous Reprceessing of Fast Breeder Fuel Elements. Common Extraction and Separation of Macroquantities of Pluconium and Uranium in the Purex Process," United States-Euratom Fast Reactor Exchange Program report EURFNR-888 (October 1970).

18. R. E. Burns, J. N. Hartley, D. H. Lester, F. P. Roberts, J. L. Swanson, and E. J. Wheelwright, "Technical and Economic Feasibility of Partitioning Hanford Purex Process Acid Waste," Battelle Northwest Laboratories repori BNWL-1907 (May 1.975).

19. W. Baehr and T. Dippel, "On the Dissolution of $\mathrm{PuO}_{2}$-Containing Breeder Fuels in Nitric Acid for Aqueous Reprocessing by the Purex Method," Karlsruhe Laboratory report KFK-673, EUR-3704d (1967).

20. J. H. Goode, "Hot-Celi Dissolution of Highly Irs\&diated $20 \% \mathrm{PuO}_{2}-80 \% \mathrm{UO}_{2}$ Fast Reactor Fuel Specimens," Oak Ridge National Laboratory repozt ORNL-3754 (October 1966).

21. W. E. Unger, "Aqueous Fuel Reprocessing Quarterly Report for Period Ending September 30, 1973," Oak Ridge National Laboratory report ORNL-TM-4394 (February 1974) pp. 13-20.

22. W. E. Unger, "Aqueous Fuel Reprocessing Quarterly Report for Period Ending December 31, 1973," Oak Ridge National Laboratory report ORNL-TM-4488 (June 1974) pp. 9-18.

23. R. K. Steunenberg, R. D. Pierce, and I. Johnson, "Status of the Salt Transport Process for Fast Breeder Reactor Fuels," Nucl. Metall. 15, 325 (1969).

24. D. C. Hampson, R. M. Fryer, and J. W. Rizzie, "Melt Refining of EBR-II Fuels," Nucl. Metall. 15, 57 (1969). 
25. I. O. Winsch, R. D. Pierce, G. J. Bernstein, W. E. Miller, and L. Burris, Jr., "ERB-II Skull Reclamation Procedure," Nucl. Metall. 15, 297 (1969).

26. N. M. Levtiz, E. L. Carls, D. Grosvenor, G. J. Vogel, and I. Knudsen, "Engineering-Scale Fluoride Volatility Studies on Plutonium-Bearirig Fuel Materials," Nucl. Metall. 15, 211 (1969).

27. M. A. Thompson, R. S. Marshall, and R. L. Standifer, "Pilot Plant Experience on Voiatile Fluoride Reprocessing of Plutonium," Nucl. Metall. 15, 163 (1969).

28. M. J. Steindler, L. J. Anastraia, L. E. Trevorrow and A. A. Chilenskas, "Laboratory Development of Fluoride Volatility Pracess for Oxidic Nuclear Fuels," Nucl. Metall. 15, 177 (1969).

29. L. J. Mullins, Los Alamos Scientific Laboratory, personal communication, October 1975.

30. S. E. Khalafalla and G. W. Reimers, "MagnetoGravimetric Separation of Nonmagnetic Solids," Trans. AIME 254, 193 (1973).

31. S. E. Khalafalla and G. W. Reimers, "Separating Nonferrous Metals in Incinerator Residue Using Magnetic Fluids," Sep. Sci. 8, 161 (1973). 